This item is the archived peer-reviewed author-version of:

Insights gained by schools and emotional consequences of school inspections : a review of evidence

\title{
Reference:
}

Penninckx Maarten, Vanhoof Jan.- Insights gained by schools and emotional consequences of school inspections : a review of evidence

School leadership and management - ISSN 1363-2434 - 35:5(2015), p. 477-501

Full text (Publishers DOI): http://dx.doi.org/doi:10.1080/13632434.2015.1107036 


\section{Insights Gained by Schools and Emotional Consequences of School Inspections. A Review of Evidence}

Maarten Penninckx (*), Jan Vanhoof

Edubron Research Unit, University of Antwerp, Belgium

University of Antwerp

Venusstraat 35

B-2000 Antwerp

Belgium

Maarten.penninckx@uantwerp.be

$+3232654143$

(*) corresponding author 


\section{Insights Gained by Schools and Emotional Consequences of School Inspections. A Review of Evidence}

This study systematically reviews research evidence regarding two questions: (1) to what extent do schools gain insight into the quality of their own functioning as a result of an inspection?; and (2) what are the emotional consequences of inspections experienced by school staff?

It provides a review of empirical research studies published as full length articles in scientific journals and proceedings of international conferences, symposia and workshops, as well as in books or as book chapters, from 1995 until 2012. Both quantitative and qualitative data are considered. The review process identified thirty-five relevant publications that met the criteria for inclusion.

The review leads to the conclusion that inspections fail to contribute significantly to schools' self-understanding, but that they lead to a severe negative emotional impact on school staff. Furthermore it is concluded that the current evidence base shows several gaps. There is no research on the question whether schools gain insights on 'how' they can improve (rather than on 'what' they can improve). The evidence base is also limited with regard to identifying underlying explanatory features that contribute to the occurrence of these effects.

\section{Introduction}

In many educational systems across the world, the external evaluation of schools is set up in order to map the quality of education and to follow up on individual schools. In Europe, the dominant arrangement for external evaluations is inspection (Van Bruggen 2010, OECD 2013). In research and policy literature, several terms have been used to describe the external evaluation of schools, such as 'supervision', 'inspection' and 'appraisal' (Macnab 2004). Several scholars have already formulated a definition of 'inspections'. An inspection has been defined as an evaluative and not merely descriptive process (van Amelsvoort et al. 2006, Janssens and Van Amelsvoort 2008, IIEP 2011), including at least one site visit (Lawrenz, Keiser, and Lavoie 2003, Boyne, Day, and Walker 2002), executed by one or more persons with specific expertise (Lawrenz, Keiser, and Lavoie 2003), who are not directly involved in the school (Penzer 2011), in order to report on the quality of schools in 
relation to national and local performance standards and legislative and professional requirements (Janssens and Van Amelsvoort 2008). Building on these definitions, we define a school inspection as "an evaluation of the quality of a school, including (minimally) a site visit, leading to a summative judgement on whether the quality of the school is meeting the expected standards, by persons with specific expertise who are neither directly nor indirectly involved in the school". This definition excludes accountability measures that don't include a site visit, as is often the case in education systems where schools are only assessed through student test scores.

Accountability at school level is becoming increasingly important. In many Western countries, there has been a trend towards granting schools more autonomy regarding their procedures (Faubert 2009, OECD 2013). This devolution of responsibility has in turn led to a more pressing need to ensure that schools are held accountable for their quality (Hofman, Dijkstra, and Hofman 2008, OECD 2013). At the same time, inspections are often justified by the assumption that they will contribute to school development Chapman 2001a, Ehren and Visscher 2006). Indeed, many policy-makers tend to see school development as an important function of inspections (Ehren, Altrichter, McNamara, and O'Hara, 2013).

There are different possibilities for conceptualising 'school development' resulting from an inspection, such as the effects of inspection on schools' policies and practices, and on teachers' professional behaviour, or on the learning outcomes of students. However, several authors have already pointed out that the evidence regarding the effects on schools' policies and practices, teachers' professional behaviour and learning outcomes does not show a coherent picture at all: while some studies found that inspections largely encourage school development, other studies observed no effect or even negative effects (Chapman and Earley 2010, Dedering and Müller 2011, Ehren and Visscher 2006). In this review study, we investigate the extent to which school inspections lead schools to gain new insights into the strengths and weaknesses of their practices and policies. Indeed, inspections cannot directly affect schools' policies and practices nor teachers' professional behaviour (Matthews and Sammons 2004). Instead it is often assumed that the development function of inspections should be understood in an indirect way: the inspectors show the school its strengths and weaknesses, which should serve as a lever by which schools can engage in processes of school development. The development effects are then perceived as a natural corollary to the new insights delivered by the inspectors (Harris et al. 2006, Ehren,

Leeuw, and Scheerens 2005, Janssens and Van Amelsvoort 2008). Several studies showed that the extent to which schools gained insights as a 
result of the inspection, has an impact on principals' and teachers' reactions towards the inspection, as well as on subsequent school and classroom development (Ehren 2010, McCrone et al. 2007, Ouston and Davies 1998).

It is important to stress that the focus of this study concerns only one assumed way in which schools benefit from inspection, namely the extent to which schools gain insight as novelties about their functioning have been revealed. Overall, two other assumed ways for school improvement through inspection have been distinguished. First, inspection may generate public knowledge: weaknesses that were known to the school, are made public, pressurizing the school to respond (Ehren, Leeuw, \& Scheerens 2005; Landwehr 2011). Also parents', students' and local policy-makers' reactions may be significant driving forces for school improvement (Ehren et al. 2013; Ehren, Leeuw, \& Scheerens 2005). Secondly, the mere existence of an accountability mechanism is believed to have a positive effect on the way schools are organized, on the teaching and learning processes in the classroom, and on the school development processes, as schools strive to meet the criteria and standards that are communicated through these forms of accountability (Ehren, Perryman, \& Shackleton 2014; Jones \& Tymms 2014; Landwehr 2011).

Undoubtedly, inspections have a profound effect on schools and their staff members. Nevertheless, the contribution of inspections to school development has always generated considerable controversy amongst teachers and educationists (Chapman 2001b, Earley, Fidler, and Ouston 1998, Nevo 2001), as the balance between advantages and the emotional side effects of inspection for principals, teachers and other staff members in inspected schools is often questioned (de Wolf and Janssens 2007). It is argued that inspections can be extremely stressful experiences (Scanlon 1999). Even the best schools are placed under strong pressure by an impending inspection and much of the stress is created by the perception that everything needs to appear faultless (McFadden 2003). Many cases are reported of fear, stress and associated negative perceptions during the preparation and the actual site visit of the inspection (Chapman 2001b, Jeffrey and Woods 1998), but also of postinspection tiredness and disillusion (Denison 2005, Sandbrook 1996) and even dramatic personal consequences (Winch 2001, Reid 2010). Not only are these negative emotional side effects undesirable, these emotions may also have an impact on the inspection itself and can jeopardise the validity and the reliability of the inspection results (de Wolf and Janssens 2007). By contrast, inspections may also result in positive emotional side effects, such as a boost in self-confidence or improved staff morale (McCrone et al. 2007). In order to conceptualise 'emotional effects', we have adopted the definition of Schutz et al. (2006), who defined 'emotions' as 'socially constructed, personally enacted ways of being that 
emerge from conscious and/or unconscious judgements regarding perceived successes at attaining goals or maintaining standards or beliefs during transactions as part of social-historical contexts' (Schutz et al. 2006, 344). This definition was promoted by Cross and Hong (2012) because of the inherent assumption that emotions involve person-environmental transactions, which include both 'internal' personal characteristics and 'external' environments (in our study, the latter constitutes 'the inspection' and 'the school context'). Both positive and negative emotional effects are included.

The two research questions central to this review address both issues outlined above. The research questions are:

(1) To what extent are insights gained by schools as a result of an inspection?

(2) What are the effects of an inspection on the emotions of school staff (including principals and members of the management team and teaching staff)?

There is ample evidence pertaining to these research questions. Several scholars conducted a literature study with the aim to bring together different empirical findings (e.g. Chapman (2001b), Chapman and Earley (2010), Ehren and Visscher (2008) and Learmonth (2000)). However, no systematic review of the effects of inspections on schools has been conducted to date. Systematic literature reviews are:

"a method of making sense of large bodies of information, and a means of contributing to the answers to questions about what works and what does not - and many other types of question too. They are a method of mapping out areas of uncertainty, and identifying where little or no relevant research has been done, but where new studies are needed" (Petticrew and Roberts 2006, 2).

A systematic review differs from a traditional literature study by its systematic approach, which is required to rule out bias in the selection of literature (Glass, McGaw, and Smith 1981). Systematic review studies select by definition a small and clearly defined subject in order to be able to stress the salient points that come out of the review (Cooper, 1988). Therefore the current review study sets a small focus: it systematically collects the evidence regarding the extent to which schools and staff members gain new insights from the inspection, and regarding the emotional side effects of inspection. It aims to bring together and integrate, in a qualitative manner, the results of all the studies that provide indications of these effects of inspections on schools and their staff members. 


\section{Review methodology}

This article reviews empirical research studies - published as full-length articles in scientific journals, international conference proceedings, as well as books or book chapters, from 1995 until 2012 - that provide evidence relating to the above research questions. We did therefore not limit our search to peer-reviewed journals, since useful sources of evidence can often be provided by other media, particularly in the social sciences (Grayson and Gomersall 2003). The publication period criterion was inspired by Wilcox and Gray's statement (1996) that, up until 1995, there were hardly any mentions of inspections in the literature on school effectiveness. This review considers both quantitative and qualitative studies. It thus does not constitute a meta-analysis, which would analyse quantitative studies only.

The relevant literature was found in early 2012, by searching electronic databases of academic resources, organizations and publishers, using the search engine EbscoHost and the following search terms: "inspection" AND "school improvement", "inspection" AND "educational improvement", "inspection" AND "schools" AND “effectiveness", "school” AND "inspection” AND “effect”, "school” AND "inspection" AND “impact", "school inspection" AND “effects", "external supervision" AND "schools", and "external assessment" AND "schools". Additionally, we looked for more studies by performing thread searches in the already selected publications.

In this initial phase, publications were considered relevant when they fulfilled the following criteria:

(1) The publication describes or explains the effects of school inspections (as defined in the introduction);

(2) The publication describes or explains either the insights gained by schools as a result of inspections, or the emotional effects on school staff as a result of the inspection (as defined in the introduction);

(3) The publication concerns an empirical study;

(4) The publication describes the methodological approach of the study;

(5) The study is directed at primary or secondary education;

(6) The publication is written in English, German or Dutch;

(7) The study was published between 1995 and 2012. 
The language criterion (6) is not only set for practical reasons, but also because most of the academic research interest has been focused on England, the Netherlands and Germany (Döbert and Dedering, 2008). Translation is based on the authors' knowledge of those languages.

\section{Results}

The results section starts with an overview of the thirty-five reviewed studies (Section 3.1). We then discuss findings related to the insights gained from inspection (Section 3.2), and finally findings related to its emotional consequences (Section 3.3).

\subsection{Overview of the studies}

The literature search resulted in the selection of forty-six publications that met the above criteria. In several cases, different publications concerned the same study and were considered only once in the scope of this review. Thirty-five studies remained for this review. An overview of these thirty-five studies is presented in Table 1.

Insert $<<$ Table 1. Overview of the reviewed studies $\gg>$

The vast majority of the studies (twenty-six studies, 74\%) were conducted in England, but relevant studies from the Netherlands, Belgium, Germany, Ireland, Northern Ireland, Sweden, New Zealand and Hong Kong are also discussed. Twelve out of the thirty-five studies (34\%) discussed in this review provided data on both the insights gained and the emotions faced by school staff. An additional six studies (17\%) gave information on the insights gained by schools, while seventeen additional studies (49\%) were found to provide data on the emotions caused by inspection. Fourteen studies (40\%) used only qualitative-data-gathering techniques (mainly interviews and group discussions) and another fourteen studies combined qualitative methods with quantitative techniques. The remaining seven studies (20\%) used only quantitative methods. 
The thirty-five studies were classified according to their methodological approach and the research question(s) for which they provided evidence (see Table 2). The studies concentrating particularly on emotional consequences relied more often on qualitative methods: fourteen out of the twenty-nine studies (48\%) on emotional consequences used only qualitative methods, while eleven studies used mixed methods (40\%). For those concentrating on the insights gained by schools, four studies out of eighteen (22\%) used only qualitative methods, while eleven studies used mixed methods $(61 \%)$.

<<Insert Table 2. Studies classified by methodology and area of research >>

The effects in both primary and secondary schools have been well documented. Seventeen studies (49\%) included both primary and secondary schools in their sample, eleven studies (31\%) focused on primary schools and a further six studies (17\%) on secondary schools. In one study it was not explicitly mentioned whether the sample schools concerned primary or secondary schools.

The number of studies conducted on the insights gained by schools or emotional consequences engendered by inspections has significantly decreased since 1995. Whereas eighteen studies were published between 1995 and 2000, during the next six years this figure almost was halved (ten studies published in the period 2001-2006), and the figure has fallen to only seven studies in the most recent six years (20072012). This decline in research is even more pronounced in England: the corresponding figure drops from seventeen studies in the first period, to seven in the second period, and only two studies in the most recent period.

It is common practice in review studies to evaluate empirical studies by means of the Maryland Scale of Scientific Methods (MSS) (Sherman et al. 1998), especially when they concern justice (the field in which the MSS was developed) or education. The MSS is a scale that provides each study with a score, depending on how well the research design controlled possible confounding reasons for certain effects besides the intervention (in this case, the inspection). The MSS ranks empirical studies from ' 1 ' (weakest) to ' 5 ' (strongest) on overall internal validity, with ' 5 ' given to well-designed and well-implemented randomized field experiments. However, applying this scale to the results in this review does not provide a promising image. All of these studies meet the criterion for Level 1 (a correlation between the inspection and the observed 
effect) and Level 2 (temporal sequence between the intervention and the observed effect), but none of the studies can be categorized at Level 3.

The criterion for Level 3 is that the study includes a comparison between two or more comparable units of analysis, in this case one school under inspection and one school not under inspection (cf. quasi-experimental approach). However, none of the studies have compared the effects in schools that have recently been inspected with schools that have not been inspected (at least, not where it relates to our research questions). Each of these studies therefore receives a score of ' 2 ' on the MSS.

\subsection{Insights gained by schools as a result of the inspection}

In this section we discuss the insights gained by schools as a result of inspections. It is important to note that we deliberately do not provide the inspection or education context of any of the studies discussed in this section. As the aim is to integrate the findings of different studies, a review study implies by definition some decontextualisation of a certain subject, in this case the effects of school inspections: notwithstanding differences in aims and operationalisations of inspections between countries (Ehren et al. 2013; OECD 2013) and within countries over time (Martin 2005; Sammons 2008), the basic idea remains in any given context that an external "expert" visits the school in order to make a summative judgement. The criteria used in selecting studies to review, however, guarantee that all studies focus on the same topic and investigate the same variables. This is the research context that is shared by all studies and on which collective empirical (contextual) evidence is thoroughly analyzed. Nevertheless, since 74\% of the studies were conducted in England (as revealed in Section 3.1), and as the effects of inspection may depend on the inspection system, we have chosen to distinguish between studies from England and studies from other countries.

\subsubsection{Studies from England}

One of the most extensive effect studies of school inspection included a pilot study (McCrone et al. 2006), a main study (McCrone et al. 2007, National Foundation for Educational Research 2009) and a smaller follow-up study with schools that had already participated in the main study (McCrone et al. 2009). In the quantitative part of the main study, 33\% of the survey respondents considered the written report very helpful in 
identifying areas for improvement, compared to $15 \%$ who considered the report not at all helpful (figures for the pilot study were respectively $25 \%$ and $16 \%$ ). $51 \%$ of the respondents felt the report was 'fairly helpful' (58\% in the pilot study). However, only $14 \%$ (strengths) and $7 \%$ (weaknesses) of the respondents reported that the inspectors had identified previously unknown strengths or weaknesses (respectively 13\% and $10 \%$ in the pilot study). Only $20 \%$ (strongly) agreed that the inspection had identified new areas for improvement (18\% in the pilot study). In the main study, $84 \%$ of the respondents claimed the school's areas for improvement had been identified by both the inspection and by the school. $15 \%$ said the areas for improvement had been identified by the school alone, and only $1 \%$ of the schools reported that these areas had been identified by the inspection alone (McCrone et al. 2007). The qualitative parts of the pilot and the main study confirmed that the inspection recommendations mostly concerned areas very similar to those areas that had already been identified as needing improvement. Nevertheless, the respondents reported that the inspection had provided insight into the need for prioritising their improvement areas, suggesting that the inspection's main contribution was its value in helping schools to prioritise actions, rather than in highlighting new areas for action (McCrone et al. 2007, McCrone et al. 2006). Furthermore, the main study's survey included the additional item 'the inspection clarified our areas for improvement', which was (strongly) agreed on by $75 \%$ of the respondents (McCrone et al. 2007).

In the follow-up study, half of all survey respondents and about two-thirds of case-study school respondents reported that the recommendations continued to be helpful, although there was also a feeling noted amongst senior leaders that recommendations were less helpful because inspectors had not provided a new perspective or highlighted new areas for improvement. This was reflected by the view that 'the inspection did not help us to improve any more than we would have done anyway' (McCrone et al. 2009, 14). Although the inspection had mostly just confirmed the self-evaluation of the school, $82 \%$ of the respondents thought that the confirmation of the self-evaluation by the inspection was valuable (McCrone et al. 2007), a finding supported by case studies in the pilot study (McCrone et al. 2006).

Evidence from seven other studies confirmed that school inspections result in a rather small quantity of new insights gained. In a qualitative study by Chapman (2002), staff in secondary schools facing challenging circumstances reported that they were already aware of the priorities for improvement identified by the inspection team before the inspection. Another qualitative study found that twenty-six out of the thirty-three inspection recommendations in five schools had already been identified by the schools before the inspectors' visit - in two cases, the 
schools had already been aware of each of the inspection's recommendations (Lonsdale and Parsons 1998). Kogan and Maden (1999) also concluded that, with a few exceptions, there was little in the inspection reports that the schools were not already aware of before the inspection (Kogan and Maden 1999, Jones et al. 1999). The LEA staff interviewed as part of Hopkins et al. (1999) mentioned that the inspectors had relied heavily on discussions, in particular with the principals of the inspected schools. As a result, the inspection reports mainly reflected the points of view of principals, without subjecting these to independent scrutiny or analysis, so they did not bring new insights for the schools into their own functioning (Hopkins et al. 1999, Watling et al. 1998).

Two studies by Wilcox and Gray $(1995,1996)$ found that the inspection reports most commonly highlighted, reinforced or confirmed issues that had already been identified and that no real surprises had come up. Although the inspections had produced almost no new insights into the schools' qualities, few respondents expressed surprise that some areas had come off worse or better than had been expected (Wilcox and Gray 1996). Matthews and Sammons (2004) reported that the most positive effect of an inspection described by primary school principals was that it provided an objective, external view of the school's strengths and weaknesses, and a focus for the school's development. Nevertheless, a minority of principals felt that inspections were not effective, as they merely confirmed the school's self-evaluation. A typical comment from one respondent was: 'Although it has felt good to have a very positive report, it feels like a waste of time and public money to confirm what we already knew, including the key issues, which were all in the school development plan already' (Matthews and Sammons 2004, 43).

Two further studies are slightly more positive about the extent to which schools gain new insights through inspection. Both these studies investigated the overlap between the key issues identified by the inspection and the priorities of the schools' own development plans. In the study of Cuckle, Hodgson, and Broadhead (1998), a complete overlap was reported by 5\% of the principals. 34\% reported very close compatibility, while the majority (52\%) of the respondents reported that the school's priorities and the inspection's key issues had 'reasonable compatibility'. $7 \%$ of the principals reported there was hardly any compatibility, while $2 \%$ of the principals felt there was no match all (Cuckle, Hodgson, and Broadhead 1998, Cuckle and Broadhead 1999). Furthermore, the survey revealed that $60 \%$ of the key issues identified in the inspection reports were already (partly or completely) in the existing school development plan, while the interviews in the same study gave a figure of $56 \%$. $22 \%$ of the key issues identified by the inspectors were not (yet) in the school development plan but were accepted as reasonable An additional 11\% 
were not explicitly mentioned in the school development plan, but the school claimed either that it planned to add them, or that it was working on the key issue already without having mentioned it in the school development plan. Overall, 67\% of the principals indicated that their single most important priority of the moment had been mentioned by both the school development plan and by the inspection report. In $22 \%$ of the schools, the most important priority was not in the school development plan, but was mentioned in the inspection report. It usually concerned a legal requirement, such as a health or safety issue, or a curriculum area that was not fully covered (Cuckle, Hodgson, and Broadhead 1998).

Ouston, Fidler, and Earley (1997) reported a major overlap between the inspection findings and the school development plan in $30 \%$ of the schools in their sample, some overlap in $53 \%$ of the schools and no overlap in $17 \%$ of the schools. They also reported that those schools with 'some overlap' found the inspection process most valuable for school development (Earley 1998, Ouston, Fidler, and Earley 1995, Ouston and Davies 1998, Ouston, Fidler, and Earley 1997). In this study, however, it remains unclear whether lack of overlap means the school had really gained new insights into its functioning, or rather that the school had not included certain issues in its school development plan because they did not agree with the inspection findings or doubted the importance of the issue. A figure indicating the share of the key issues not in the school development plan, but considered by the school as reasonably identified by the inspectors (as was provided in the study of Cuckle, Hodgson, and Broadhad (1998)), would have been more useful for our purposes.

Finally, the study of Scanlon (1999) stands out as it compares the insights gained by a quasi-experimental group of schools in special measures (or recently removed from special measures), and a control group of schools that had never been in special measures. Schools are placed into special measures when they do not meet the requirements set by OFSTED and when they are judged to lack the capacity to secure that weaknesses will be adequately addressed (DFES 2005). Schools in special measures need to amend their action plans and several restrictions are placed upon the schools, such as restrictions on the employment of newly qualified teachers. These schools receive very regular monitoring inspections, up to five times over two years. $69 \%$ of the schools in the control group reported that they had expected all or most of the key issues for action identified by the inspection team, while this was the case for only $56 \%$ of the schools in special measures. Only $18 \%$ of the schools in the control group reported that fewer than half of the key issues were expected, compared to $28 \%$ of the schools in the quasi-experimental group (Scanlon 1999). 


\subsubsection{Studies from other countries}

In a study by Schagen and Wylie (2009) in New Zealand, 30\% of the schools reported that they had gained new insights as a result of the inspection with regard to their own school. $23 \%$ of the principals claimed that they had learned nothing from the inspection. $30 \%$ of the schools surveyed by the Swedish National Financial Management Authority said they were aware of the identified weaknesses before the inspection, while 54\% of the schools were partly aware of them (Olsson 2007). Similarly, 35\% of the Dutch schools surveyed by Emmelot et al. (2004) reported that each of the identified deficiencies had already been identified by the school. This was partially the case in $57 \%$ of the schools; in only $8 \%$ of the schools, the weaknesses had not yet been identified by the school.

The abovementioned studies confirm the results obtained in the English education context. Our review revealed only one study that clearly stands out; according to the study of Macbeath (2008) in Hong Kong, the inspection helped staff to identify the strengths and weaknesses of the schools. $71 \%$ of the respondents agreed that the inspection had helped them devise future goals and development plans. Furthermore, around $80 \%$ of the teachers agreed that the inspection had helped them reflect on the effectiveness of their daily practice.

\subsection{Emotions engendered by inspections}

In this section, the emotional consequences of inspection are discussed. As was the case in the previous section, we do not provide a full context for each of the single studies. We first discuss English studies, followed by the evidence available from other countries.

\subsubsection{Studies from England}

Brimblecombe and Ormston (1995) concluded that the most stressful stage of inspection was the period between notification of inspection and the actual site visit. Stress levels increased up to the week before the site visit, decreased during the site visit, but remained apparent, to a lesser extent, for a number of weeks after the inspection. The post-inspection stress was partly explained by fears concerning (the lack of anonymity in) the inspection report, especially when teachers had not received informal feedback after their lesson observation. Absenteeism amongst teachers 
is higher than usual in the week after the site visit but it was found that these side effects were less likely to occur in schools where a 'measured, proactive approach' had been taken towards inspection. The extent to which teachers regard an inspection as an opportunity for them, or as something that is done to them, has an influence on their anxiety levels before the site visit. Stress levels increased when teachers didn't know when the inspector would enter their classroom, and when they weren't given informal feedback directly after the classroom observation. It was concluded that stress was likely to be caused in part by fear of the unknown (Brimblecombe and Ormston 1995, Brimblecombe, Shaw, and Ormston 1996). Fear could be relieved by the inspectors' presenting themselves in a benign manner and encouraging staff to perceive the inspection as a shared process, and when the inspectors' behaviour was perceived as reassuring and helpful (Brimblecombe and Ormston 1995).

Alongside the inspectors' attitude, the attitude of the principal also has an impact on teachers' emotional experience of the inspection: principals who helped staff to meet the inspection with support and reassurance had a stress-reducing effect, while panic measures were found to increase stress among staff (Brimblecombe and Ormston 1995). The burden placed on staff to "tell [the inspectors] the right things" was also a cause of stress. The position of staff within the school also explained some of the stress experienced. Approximately a third of senior managers expressed negative feelings, compared to just over half of the teachers; teachers were more worried and felt more resentment, possibly due to their lower degree of self-determination, as teachers were less involved in preparations for the inspection and therefore had less control over the process. Furthermore, significantly more female staff members felt worried about the inspection than male staff members (Brimblecombe and Ormston 1995, Brimblecombe, Shaw, and Ormston 1996).

Brunsden, Davies, and Shevlin (2006) measured the stress and anxiety levels of teachers and non-teaching staff members in a primary school on three occasions, prior to and after the inspection, using two self-report personality measures in validated psychodiagnostic questionnaire. Their findings confirmed the above conclusion that teachers suffer from more emotional side effects than non-teaching staff: during each of the three measurements, both trait anxiety and state anxiety, as well as stress levels, were higher for teachers than for non-teaching staff. Teachers' trait anxiety levels were higher than what was considered as the norm for working adults, and a fortnight before the site visit, they even were as high as the norm that is used to identify neuropsychiatric patients. Teachers also displayed high levels of state anxiety: they started at levels consistent with scores expected from psychiatric patients three months before the inspection, and the figures rose even higher 
two weeks prior to the inspection. Furthermore, $56 \%$ of the teachers scored on or above the norm for 'clinically significant' stress three months before the site visit, and $88 \%$ showed clinically significant stress levels two weeks before the site visit. The high levels of stress, trait anxiety and state anxiety had decreased ten weeks after the site visit, but still remained higher than the norm for regular working adults. Clinically significant stress was still noted in $44 \%$ of the teachers, even though the school in which this study was conducted had by then received a favourable report. Therefore the researchers suggest that 'it is the inspection experience itself and not its outcome that is generating the psychological distress' (Brunsden, Davies, and Shevlin 2006, 28).

Wilcox and Gray (1996) also found that teachers displayed more anxiety concerning upcoming inspections than senior managers. They concluded that teacher anxiety is associated with being observed teaching. Meetings between school staff and the inspectors before the site visit were observed to reduce anxiety, while increased anxiety was reported when teachers had not received informal feedback directly after the classroom observation (Wilcox and Gray 1996). In another study Wilcox and Gray (1995) referred to the emotional consequences experienced by teaching staff at one case school (that did not agree with the inspectors' negative assessment) as 'trauma' and 'shock'.

The effects described in several other studies contribute to evidence regarding the 'loss of professional identity' and 'post-inspection blues'.

Loss of professional identity. The 'loss of professional identity' refers to teachers losing their self-confidence and starting to ignore their own professional ideas in favour of acting as they think the inspection expects them to act, thereby losing any sense of autonomy. This is documented by the study of Jeffrey and Woods (1996) (and for schools in special measures, by Scanlon (1999) and Perryman (2005, 2006, 2007, 2009), as will be discussed later). Jeffrey and Woods (1996) observed that teachers began to doubt their competence, as the inspection "had reminded them how short of perfection they fell" (Jeffrey and Woods 1996, 332). This effect was more obvious in teachers that are highly conscientious and involved. Furthermore, this study reported feelings of anger, despair, depression, humiliation, grief and guilt, due to the mismatch school staff were experiencing between the inspection and their own beliefs and past experiences. This study also described a sense of emotional confusion. Positive feelings were marginalised and there was a decline in the use of humour, teachers' usual main coping strategy (Jeffrey and Woods 1996). 
Post-inspection blues. The concept of 'post-inspection blues' refers to a state of exhaustion, burnout, feelings of disillusion and tiredness (Ferguson et al. 1999). Indications for this phenomenon are described by seven different studies (as well as by Scanlon (1999) for schools in special measures, see below). $86 \%$ of the principals surveyed by Ferguson et al. (1999) reported encountering lower staff enthusiasm and increased absenteeism and exhaustion, for (on average) between 4.5 and 5 months, but in some cases up to a whole year, after the inspection.

Cases are reported in which strong teachers left the school because they felt defeated when the school received a negative evaluation. Webb et al. (1998) revealed inspections cause an intensification of stress, loss of confidence, feelings of inadequacy, deprofessionalisation and extreme anxiety. Stress was apparent in the run-up to the inspection, but side effects were also noticed after the inspectors had left. In one school, demotivation and inertia lasted up till 18 months after inspection, in spite of the positive evaluation it had received. Lonsdale and Parsons (1998) stated that normal school life was disturbed for at least three months after the inspection, due to the cumulative effect of stress, panic and pressure in the preparation period, but also because of the expectance of the inspection report. In the study by Ouston, Fidler, and Earley (1997), 'many' schools' reported slowing things down while recovering from the inspection and development ceased for a short time, often until halfterm or the end of the term, although over two thirds of the principals found the inspection report encouraging, compared to $21 \%$ who were dispirited in some way (Ouston, Fidler, and Earley 1995, Ouston and Davies 1998, Ouston, Fidler, and Earley 1997). Case, Case, and Catling (2000) collected evidence of increased staff tiredness up to one year after an inspection, and a loss of self-confidence amongst teachers, regardless of the inspection's judgement. Teachers experienced anxiety more often, even when they were expecting a positive report for themselves and for the school (Case, Case, and Catling 2000).

Sandbrook (1996) concluded that teachers suffered from fatigue and apprehension, and that they were anxious about losing control in the classroom during the observation by the inspectors. Anxiety rose when the teachers didn't receive feedback after the classroom observation: 'a lack of feedback increases anxiety: everyone assumes the negative' (Sandbrook 1996, 62). Teachers' professional self-confidence is perceived as a key influence on the stress levels experienced: the more self-confident a teacher was, the less likely s/he was to suffer from high levels of stress. The inspection seemed to result in a crisis of self-confidence and in lower staff morale, in some cases further deteriorated by the behaviour of the principals who put pressure on staff (Sandbrook 1996). Finally, Kogan and Maden (1999) indicated that the inspection had resulted in a climate 
of fear in the schools, generating stress and anxiety. The long period between the notification and the actual site visit led to added 'anticipatory dread'. After the inspection, tiredness, lack of motivation and decreased morale were observed, as well as an increase in absence caused by stress in $24 \%$ of the schools.

Other studies. Eight further English studies have provided additional or confirmatory insights into the effect of school inspections on the emotions of various staff members in schools. McCrone et al. (2006) found $57 \%$ of the respondents (strongly) agreed that the inspection had helped to boost morale, yet only a slightly smaller proportion (41\%) expressed disagreement with this statement. The figures provided by McCrone et al. (2007) were even more inconclusive: $51 \%$ of respondents agreed that the inspection had helped to boost staff morale, while $46 \%$ disagreed. Another study observed low morale amongst teachers due to a feeling of having let the new principal, the school and the children down (Hosker and Robb 1998). Chapman (2001a) found that 62\% of teachers felt apprehensive about having an inspector in their classroom. Chapman (2002) reported high levels of stress and a lack of job satisfaction amongst teachers, due to the inspection. Some teachers held the inspection responsible for stress-related illness. In one school, studied by Troman (1997), a culture of fear had been established by the principal who put continuous pressure on the staff to change in order to align with the inspectors' expectations. Finally, the study of Hopkins et al. (1999) found stress and anxiety amongst staff members before the site visit. It is suggested that the increased stress and anxiety disappeared immediately after the site visit, giving way to a feeling of elation, which was in turn replaced by a pervading sense of disillusion, 'a feeling that the results were far less dramatic, the exercise less worthwhile, the improvement far less permanent' (Hopkins et al. 1999, 686).

Schools in special measures. Scanlon (1999) provided empirical evidence for the loss of professional identity amongst staff members in schools in special measures (explained above in Section 3.2.1), citing teachers of these schools as stating: 'You are made to feel totally incompetent. You are made to feel that everything you've done for the last 20 years in teaching is absolutely useless' (Scanlon 1999, 33). The results of this study showed that about $25 \%$ of the teachers, and over $30 \%$ of principals of schools in special measures, experienced a sense of depression and despondency after inspection. Teachers in schools in special measures didn't tell others which school they worked in anymore. $25 \%$ of teachers, and over $20 \%$ of the principals of schools in special measures, said they were surprised or shocked by the outcome (compared to less than $5 \%$ at 
other schools), even when the outcome was more or less expected. 60\% of the teachers in schools in special measures (the quasi-experimental group) felt stressed most or all of the time, compared to $36 \%$ of their counterparts in other schools (the control group). Furthermore, the 'failing' schools faced more staff absences due to stress or illness in the semester after the inspection (24\% of principals and $38 \%$ of teachers in the quasiexperimental group, compared to $17 \%$ and $24 \%$ in the control group), and staff members in schools in special measures more often claimed that their stress or illness was related to the inspection. Nevertheless, when staff were asked whether they felt an uncomfortable amount of pressure due to increased workload for the inspection, the figures didn't reveal a significant difference between schools in special measures and schools that had never been in special measures. In both groups, just over $70 \%$ of teachers and principals agreed with this statement. Principals of schools in special measures were more positive about the effects of inspections on staff morale: $50 \%$ thought that the inspection had brought about an improvement, while $32 \%$ observed a deterioration of staff morale. In the control group, only $17 \%$ saw an improvement while $36 \%$ saw a deterioration. The teachers' views, however, differ from their principals' views: only $25 \%$ of the teachers in schools in special measures saw an improvement in morale (17\% in other schools), while 58\% saw a deterioration (48\% in other schools). This study also reported that staff members found it difficult to feel motivated after an inspection, because so much time and effort is put into the preparation (see post-inspection blues). This applies to respondents from both the quasi-experimental and the control groups. Finally, this study pointed out that schools with a strong team spirit and mutual support mechanisms were better equipped to cope with the negative side effects of inspections and thus less stress was experienced in those schools (Scanlon 1999).

In one school in special measures, Perryman (2005, 2006, 2007, 2009) documented teachers and principals starting to behave in the manner they thought was expected of them, thereby ignoring their own professional ideas, which led to feelings of helplessness, lack of control and feeling like a failure, adding up to a loss of professional identity (Perryman 2006, 2007). This loss of professional identity remained even when the school was taken off the special measures regime (Perryman 2005). Furthermore, this study observed frustration amongst the staff with the externally-imposed systems, as well as fatigue, exhaustion and fear, mainly instigated by the potential consequences of the inspection (Perryman 2007). 
Nicolaidou and Ainscow (2005) found that teachers in schools in special measures were disappointed, and felt 'useless' and 'a failure', while the subsequent inspections (as a result of the schools being placed in special measures) placed immense pressure on staff, which led to frustration, feelings of worthlessness, conflict and a decreased sense of cohesion among staff. Finally, a study in special schools in special measures (Thomas, Yee, and Lee 2000) also observed feelings of anger, depression and shame resulting from negative evaluations.

\subsubsection{Studies from other countries}

In the Northern Irish study by Gray and Gardner (1999), 34\% of the principals report high levels of stress before an inspection among most of the staff members, while the corresponding figure in secondary education was only $21 \%$. The (smaller) focused inspections in secondary education are seen as the cause for these lower levels in secondary schools. The high levels of stress resulted several medical problems. Also other emotional responses (such as worry, fear and resentment) and a rise in inter-staff tensions were reported.

In Ireland, a study of eight schools reported considerable fear and trepidation in the run-up to an inspection (McNamara and O'Hara 2006). Fear, however, was dispelled through the professional, collegial and nonthreatening approach of the inspectors. Teachers from schools with disadvantaged students felt particularly strongly valued by the 'affirmation of good practice' provided by the inspectors (McNamara and O'Hara 2006). A study in Hong Kong by Macbeath (2008) found that teachers experienced stress mainly because of the need for documentation and the classroom observation. The effectiveness of the principal's leadership was a determining factor in the stress levels experienced by the teaching staff.

Loss of professional identity was observed in principals, in a Belgian study assessing the effects of inspection in twelve case schools (Kelchtermans and Vandenberghe 1998). Because the inspection did not only give the schools an insight into their own functioning, but also indirectly communicated a concept of 'good teaching' and how to achieve predetermined goals, principals felt threatened in their professional identity. The absence of feedback after classroom observation left teachers with uncertainty, self-doubt and powerlessness.

The only results that seemed to (partially) differ from the evidence in the English context were those collected by Gärtner, Hüsemann, and Pant (2009) in a German study. In their study 3.8\% of the principals reported fear and sorrow, pressure or frustration. The authors suggested 
these lower figures might be due to the lower stakes compared with inspections in England. However, their findings were questioned by another German study, with a sample of twenty-seven schools that had received negative inspection reports (Sommer and Schwank 2011), which concluded that $60 \%$ of the principals thought that this report was hard on them, while $80 \%$ reported that it increased staff dissatisfaction and the need for staff counselling. The negative inspection reports led, in about $90 \%$ of the schools, to frustration amongst staff, lasting up to three months (30\%), up to six months (40\%), up to one year (about 5\%) or even longer (about 15\%).

\section{Conclusion and discussion}

This study has collected abundant evidence suggesting that inspections do not contribute significantly to schools' self-understanding.

Furthermore, there is strong evidence of severe negative emotional impact on teachers and, to a lesser extent, non-teaching staff.

The number of studies regarding the insights gained by schools as a result of an inspection, along with their emotional consequences, has gradually declined (see Section 3.1), especially in England. The high number of studies between 1995 and 2000 may have been due to the sudden establishment of the inspection agency Ofsted, which was a radical change from the accountability measures that were in place before (Gray and Wilcox 1995, Thomas 1998, Earley, Fidler, and Ouston 1998). It is plausible that, due to adjustments to the design of Ofsted inspections and adaptations to its implementation, the dust has settled somewhat with regard to the effects of inspections, and research interest has subsequently subsided.

The contexts of the studies were not included in the article, as a review inevitably entails some decontextualisation of its subject. It was not the intention of this review to investigate the effects of different policy contexts on the effects of school inspections. Not only would it be impossible to describe these different national contexts in detail, the inspection systems have also passed through different configurations over time: studies in the early days of OFSTED have been conducted in a context that differs strongly from the inspection context in more recent research. Moreover, this review revealed that $74 \%$ of the studies were conducted in England, so it is likely that a comparative review into the effects of policy contexts on the effects of school inspections would prove rather disappointing. Furthermore, the lack of a clear conceptualisation of effects and side effects in most studies - often remaining vague about what exactly is measured - impedes any real comparison of the results 
observed in different education systems. For instance, if the inspection results in increased 'stress', a conceptual clarification of 'stress' is needed. It is imperative that a strong conceptual framework is developed, identifying the assumed effects and side effects, as well as potentially explaining features of these (side) effects, in order to allow these variables to be assessed in different education contexts, using quality research strategies. Indeed, despite the relatively high number of studies, we conclude that the evidence base is rather weak and is in need of more focused research, based on a common framework.

\section{Insights gained as a result of an inspection}

From the overview discussed in Section 3.2, we may conclude that the extent to which schools have gained new insights is rather limited. Although two of the studies showed instances in which a school's development plan and the key issues identified in that school's inspection demonstrated 'reasonable compatibility' (indicating that the inspection had effectively added some new key issues to the school's priorities), all of the remaining studies from England showed that inspections did not result in substantial new insights for those schools. The results of a study conducted in Hong Kong (Macbeath 2008) count as the only exception to these rather negative results, but differing approaches and research questions impede a real comparison.

Both quantitative and qualitative approaches have been used to investigate the extent to which schools gained new insights as a result of an inspection. No substantial differences could be observed in the results of those studies depending on the research method. The fact that almost all of the reviewed studies with various research methodologies reached similar results, adds weight to the above conclusion about the insights schools gain from an inspection.

The absence of new insights into the schools' own functioning does not mean that there is no school development after inspection. Several studies have confirmed that schools and teachers developed and implemented action plans after being inspected (e.g. McCrone et al. 2007, Dedering and Müller 2011, Scanlon 1999). As these actions are not the result of new insights, it should first be enquired what has engendered these initiatives and secondly whether these initiatives are supported by the schools and teachers, or whether they are extrinsicallymotivated actions. A number of possible explanations have been suggested by the reviewed studies: for example, inspections can help schools 
prioritise their plans for improvement; inspections can be helpful in clarifying and deepening a school's insight into issues it is already aware of; and finally, the confirmation provided by an inspection of a school's own analysis of its strengths and weaknesses can be regarded as helpful and empowering (McCrone et al. 2007, Schagen and Wylie 2009). Scholars have raised several counterarguments that put the objectivity of an inspection's judgement into question (for example, that inspections struggle with reliability and validity issues (e.g. Gärtner and Pant 2011, Gray and Wilcox 1995, Waldegrave and Simons 2014); that inspections are too limited to assess pre-determined aims during a short site visit (e.g.

Richards 2001, Gilroy and Wilcox 1997); or that principals often lack confidence in an inspection's judgement (Fidler et al. 1998)). Nevertheless, schools seem to value the external validation that they are on the right track as an important lever for further school development. Several studies have shown that, when the conceptions of the principal or a considerable number of teachers have been confirmed, the inspection report adds an authority and legitimacy to the schools' plans and thus acts as a catalyst to bring about change or to accelerate developments that have already been planned (Wilcox and Gray 1996, Hosker and Robb 1998, Schagen and Wylie 2009). Sometimes, the confirmation provided by the inspection is even used as a lever to implement unpopular measures at the school (Cuckle and Broadhead 1999). Another possible explanation for school improvement in spite of not having gained new insights, is that the previously 'tacit knowledge' (only known by the schools) has been made public by the inspection, which puts pressure on the schools to address these issues (Ehren, Leeuw, \& Scheerens, 2005; Landwehr, 2011).

As a final remark, this review has resulted in an overview of studies that provide insight into the particular question of whether schools gain insight as a result of an inspection into their strengths and weaknesses. The question whether schools gain insight into the question how they can address their weaknesses, or how they can improve their current quality, was not answered by this review, for the simple reason that no evidence was found regarding this issue. It is unclear whether this lack of evidence means there are no new insights regarding how to improve, or that researchers just haven't yet investigated this question.

\section{Emotional consequences}

Each of the twenty-eight reviewed studies has provided evidence of negative emotions amongst school staff as a result of inspections, albeit to different degrees. Inspections lead to an increase in stress, anxiety, anger, apprehension and other negative emotions. Some authors observed 
severe negative emotional effects on school staff from inspections, leading to 'post-inspection blues' and the 'loss of professional identity'. Only one study reported increased self-confidence, while evidence of effects on staff morale, discussed by three studies, is inconclusive.

Various indications have been provided for explanatory features of these emotional side effects. However, most of these features were mentioned by only one of the studies. The features that were mentioned by more than one study were: whether teachers had received (informal) feedback after being observed (Wilcox and Gray 1996, Sandbrook 1996, Brimblecombe and Ormston 1995), and whether teachers had received adequate information on what was about to happen (Wilcox and Gray 1996, Brimblecombe and Ormston 1995). Additionally, the position and behaviour of the principal proved paramount (Brimblecombe and Ormston 1995, Troman 1997, Macbeath 2008). Staff members in teaching positions seem to suffer from greater stress and anxiety compared with non-teaching staff (Brunsden, Davies, and Shevlin 2006, Brimblecombe and Ormston 1995, Wilcox and Gray 1996).

As discussed in Section 3.1, researchers have often preferred qualitative research methods to quantitative methods when studying emotional consequences. As almost all studies have resulted in similar conclusions, no substantial differences could be observed in the results of those studies depending on the research method.

Positive side effects have hardly been mentioned in the results section. A plausible conclusion could be that hardly any positive emotions are engendered by inspections, but this finding may also just be the result of the research community having neglected the issue of positive emotional effects. This latter assumption needs further clarification.

\section{General discussion}

We conclude this study with some key remarks on the current state of research, and suggest further research that should be conducted regarding both new insights gained by schools as a result of an inspection, and their emotional consequences.

We didn't restrict our selection to studies that 'describe' effects of inspection, but included studies that 'explain' those effects. However, we found research on 'explanatory factors' of insights gained by schools to be almost non-existent and discussions on explanatory factors concerning emotional consequences are mostly limited to 'indications' and hardly ever based on substantiated evidence. We conclude that the 
current research base cannot assist in an understanding of the features that explain either whether or not schools gain new insights, or the extent to which staff members undergo emotional effects, from an inspection. Explanatory studies are therefore warranted, to probe the extent to which the inspectors' judgement, alongside other features of the inspection and the school, explain the effects and side effects of an inspection. A

related issue lies with the causality of the findings in most studies. For instance, several studies have observed pronounced stress levels amongst teachers before, during and after inspection, but studies unrelated to inspection have also shown that the intensity of the teaching profession leads to high stress levels for many teachers throughout their entire teaching career (Vandenberghe and Huberman 1999, Troman and Woods 2009).

The question remains to what extent these stress levels can be attributed to inspection? And similarly, what are the exact features that engender stress?

In the above paragraphs, we have extensively shown that, regarding both insights gained and emotional consequences engendered by school inspections - and particularly regarding the causes of these effects - much is still left blank. Therefore, an investigation into the extent to which these insights and emotional consequences actually have been influenced by (changing) inspection policies and practices is much warranted. This, however, requires not only a wider research diversity and a clear conceptual framework allowing for comparative research, but also more cause-oriented research enabling the identification of inspection characteristics that might strengthen the insights gained by schools and minimize the emotional burden of school inspections. Moreover, we advocate quasi-experimental studies in which schools under inspection are compared to schools that have not been subject to inspection, in order to increase the internal validity of the results; such studies would also be rewarded with a higher score on the Maryland Scale of Scientific Methods. Future researchers should also note that a considerable amount of the evidence reviewed is based on surveys or interviews with principals, which may have a skewing effect on the results of this review. Dedering and Müller (2011) argued that this approach can only reveal an incomplete picture of the situation. There is a certain risk of only acquiring socially-desirable answers, since principals are likely to wish for a positive representation of their schools. It is advised that, at the very least, teachers' ideas on the effects and side effects of inspection become the subject of more extensive research.

With regard to educational policy, this review leads to the recommendation to examine ways to strengthen the extent to which principals, teachers and other staff members in inspected school gain new insights, and to minimize the emotional impact. The most prominent discussion 
for adapting the current inspection mechanisms throughout the past two decennia with the purpose to increase intended effects and decrease side effects, is whether schools' self-evaluations can have a role in inspection. Several scholars have strongly advocated to use the school's selfevaluation as a basis for the inspection (Barber 1998, Hargreaves, 1995, McNamara, O'Hara, Lisi and Davidsdottir 2011), or to let the relative prominence of self-evaluation in inspection depend on the internal competence of schools to undertake self-evaluation effectively (Chapman and Earley 2010). Several education systems have experimented with combinations of internal and external evaluations (OECD 2013). To a lesser extent than the issue above, scholars have discussed whether inspections can be conducted by "peer reviewers", either alone or in combination with "professional inspectors" (Baxter and Clarke 2013, Faubert 2009) or whether the inspection can take on a more empowering role in training and guiding schools/principals to ensure their educational quality (Grek 2013, Mackinnon 2011). It can finally be concluded that, while much is known, still more remains under-researched when it comes to the effects of school inspections on schools. Those areas that need further investigation have been identified by this review. Leaving this field of research blank risks creating a context in which schools let themselves be led by 'nightmare stories'. Instead, we advocate more high-profile thematic research that can describe and explain the effects of school inspections, and from which the results can be extensively communicated with academics, policy makers and practitioners. 


\section{References (reviewed articles marked by $(*)$}

Barber, M. 1998. "The Dark Side of the Moon: Imagining an End to Failure in Urban Education." In No Quick Fixes. Perspectives on Schools in Difficulty, edited by Louise Stoll and K. Myers, 17-33. Bristol, UK: Falmer Press,

Boyne, G., P. Day, and R. Walker. 2002. "The evaluation of public service inspection: a theoretical framework." Urban Studies 39:1197-1212.

Brimblecombe, N., and M Ormston. 1995. "Teachers' perceptions of school inspection: A stressful experience." Cambridge Journal of Education 25:53-61. (*)

Brimblecombe, N., Marian Shaw, and Michael Ormston. 1996. "Teachers' intention to change practice as a result of OFSTED school inspections." Educational Management, Administration and Leadership 24 (4):339-354. (*)

Brunsden, Vivienne, Mark Davies, and Mark Shevlin. 2006. "Anxiety and stress in educational professionals in relation to Ofsted." Education Today 56:24-31. (*)

Case, P., S. Case, and S. Catling. 2000. "Please show you're working; a critical assessment of the impact of Ofsted inspection on primary teachers." British Journal of Sociology of Education 21 (4):605-621. (*)

Chapman, C. 2001a. "Changing classrooms through inspections." School Leadership and Management 21:59-73. (*)

Chapman, C. 2001b. "Unlocking the potential: inspection as a mechanism for school improvement." Improving Schools November (4):41-50. (*)

Chapman, C. 2002. "Ofsted and school improvement: teachers' perceptions of the inspection process in schools facing challenging circumstances." School Leadership \& Management 22:257-272. (*)

Chapman, C, and P. Earley. 2010. "School inspection/external school evaluation." In International Encyclopedia of Education (Third Edition), edited by P. Peterson, E. Baker and B. McGaw, 719-725. Oxford: Elsevier.

Cooper, H. M. 1988. Organizing knowledge syntheses: A taxonomy of literature reviews. Knowledge in Society, 1(1), 104-126. doi: 10.1007/BF03177550

Cross, Dionne I., and Ji Y. Hong. 2012. "An ecological examination of teachers' emotions in the school context." Teaching and Teacher Education 28 (7):957-967. doi: 10.1016/j.tate.2012.05.001.

Cuckle, P., and P. Broadhead. 1999. "Effects of Ofsted inspection on school development and staff morale." In An inspector calls: Ofsted and its effects on school standards, edited by C. Cullingford, 176-187. London: Kogan Page. (*)

Cuckle, P., J. Hodgson, and Pat Broadhead. 1998. "Investigating the relationship between OfSTED inspections and school development planning." School Leadership \& Management 18:271-83. (*)

de Wolf, I.F., and F.J.G. Janssens. 2007. "Effects and side effects of inspections and accountability in education: An overview of empirical studies." Oxford Review of Education 33:379-396.

Dedering, K., and S. Müller. 2011. "School improvement through inspections? First empirical insights from Germany." Journal of Educational Change 12:301-322. (*)

Denison, Patricia. 2005. "Beat those Ofsted blues." Times Educational Supplement (4635):30-30.

DFES. 2005. "Schools Causing Concern." edited by Department for Education and Skills,

Döbert, H., and K. Dedering. 2008. "Externe Evaluation Von Schulen in Vergleichender Perspektive - Eine Einführung [External School Evaluation in Comparative Perspective - An Introduction]" In Externe Evaluation Von Schulen, edited by H. Döbert and K. Dedering, 11-22. Waxmann: Münster,

Earley, P. 1998. "School improvement and OFSTED inspection: the research evidence." In Improvement through inspection? Complementary approaches to school development, edited by P. Earley, B. Fidler and J. Ouston, 11-22. London: David Fulton Publishers. (*)

Earley, P., B. Fidler, and J. Ouston, eds. 1998. Improvement through inspection? Complementary approaches to school development. London: David Fulton Publishers.

Ehren, M.C.M. 2010. "Effecten van toezicht op het basisonderwijs [Effects of inspection on primary education]." Pedagogische studieën 87:165-182.

Ehren, M.C.M., H. Altrichter, G. McNamara, and J. O'Hara. 2013. "Impact of School Inspections on Improvement of Schools-Describing Assumptions on Causal Mechanisms in Six European Countries." Educational Assessment Evaluation and Accountability 25: 3-43.

Ehren, M.C.M., F.L. Leeuw, and J. Scheerens. 2005. "On the impact of the Dutch Educational Supervision Act: analyzing assumptions concerning the inspection of primary education." American Journal of Evaluation 26:60-76. 
Ehren, M., J. Perryman, and N. Shackleton. 2014. "Setting expectations for good education: how Dutch school inspections drive improvement." School Effectiveness and School Improvement 26 (2):296-327. doi: 10.1080/09243453.2014.936472.Ehren, M.C.M., and A.J. Visscher. 2006. "Towards a theory on the impact of school inspections." British Journal of Educational Studies 54 (1):51-72.

Ehren, M.C.M., and A.J. Visscher. 2008. "The relationship between school inspections, school characteristics and school improvement." British Journal of Educational Studies $56(2): 205-227$.

Emmelot, Y., S. Karsten, G. Ledoux, and A. Vermeulen. 2004. Ervaringen met het vernieuwde onderwijstoezicht. Amsterdam: SCO/Kohnstamminstituut (*)

Faubert, V. 2009. "School Evaluation: Current Practices in Oecd Countries." In OECD Working Papers. Paris: OECD.

Ferguson, N., P. Earley, J. Ouston, and P. Fidler. 1999. "New heads, OFSTED inspections and the prospects for school improvement." Educational Research 41:241-249. (*)

Fidler, B., P. Earley, J. Ouston, and J. Davies. 1998. "Teacher gradings and OFSTED inspections: help or hindrance as a management tool?" School Leadership and Management 18:257-270.

Gärtner, H., D. Hüsemann, and H.A. Pant. 2009. "Wirkungen von Schulinspektion aus Sicht betroffener Schulleitungen. Die Brandenburger Schulleiterbefragung." Empirische Pädagogik 23 (1):1-18.

Gärtner, H., and H.A. Pant. 2011. "How valid are school inspections? Problems and strategies for validating processes and results." Studies in Educational Evaluation 37:8593. $(*)$

Gilroy, P, and B. Wilcox. 1997. "OFSTED, criteria and the nature of social understanding: A Wittgensteinian critique of the practice of educational judgement." British Journal of Educational Studies 45 (1):22-38.

Glass, G.V., B. McGaw, and Mary Lee Smith. 1981. Meta-analysis in social research. London: Sage Publications.

Gray, J., and J. Gardner. 1999. "The impact of school inspections." Oxford Review of Education 25:455-468. (*)

Gray, J., and B. Wilcox. 1995. Good school, bad school: evaluating performance and encouraging improvement. Buckingham, UK/Philadelphia, USA: Open University Press.

Grayson, L., and A. Gomersall. 2003. A difficult business: finding the evidence for social science reviews. London: ESRC UK Centre for Evidence Based Policy and Practice, University of London.

Grek, S. 2013. "'Living the Talk'? Inspecting as a Learning Act." In European Conference of Educational Research. Istanbul.

Hargreaves, D.H. 1995. "School Culture, School Effectiveness and School Improvement." School Effectiveness and School Improvement 6: $23-46$.

Harris, A., C. Chapman, Daniel Muijs, Jennifer Russ, and Louise Stoll. 2006. "Improving schools in challenging contexts: Exploring the possible." School Effectiveness and School Improvement 17 (4):409-424.

Hofman, R.H., N.J. Dijkstra, and W.H.A. Hofman. 2008. "Internal versus external quality management." International Journal of Leadership in Education: Theory and Practice 11 (3):281-300.

Hopkins, D., A. Harris, Rob Watling, and J. Beresford. 1999. " From inspection to school improvement? Evaluating the accelerated inspection programme in Waltham Forest." British Educational Research Association Journal 25:679-690. (*)

Hosker, H., and S . Robb. 1998. "Raising standards and raising morale: a case study of change." In School Improvement after Inspection? School and LEA Responses, edited by P. Earley, 86-96. London: Paul Chapman Publishing. (*)

IIEP. 2011. Supervision: a key component of a quality monitoring system. In Reforming school supervision for quality improvement, edited by UNESCO/IIEP. Paris: International Institute for Educational Planning.

Janssens, F.J.G., and G. H. W. C. H. Van Amelsvoort. 2008. "School self-evaluations and school inspections in Europe: An exploratory study." Studies in Educational Evaluation 34:15-23.

Jeffrey, B., and P. Woods. 1996. "Feeling deprofessionalized: the social construction of emotions during an Ofsted inspection." Cambridge Journal of Education 26:325-343. $(*)$

Jeffrey, B., and P. Woods. 1998. Testing teachers: The effect of school inspection on primary teachers. London: Falmer Press. 
Jones, K., and P. Tymms. 2014. "Ofsted's role in promoting school improvement: the mechanisms of the school inspection system in England." Oxford Review of Education 40 (3):315-330. doi: 10.1080/03054985.2014.911726.

Jones, S., V. Beale, Maurice Kogan, and Margaret Maden. 1999. The Ofsted system of school inspection: An independent evaluation. Uxbridge: Brunel University. (*)

Kelchtermans, G., and R. Vandenberghe. 1998. "Internal use of external control and support for quality improvement. The response to a national policy by primary schools." Annual Meeting of the American Educational Research Association, San Diego, April 13-17, 1998. (*)

Kogan, Maurice, and Margaret Maden. 1999. "An evaluation of evaluators: The Ofsted system of school inspection." In An inspector calls: Ofsted and its effect on school standards, edited by C. Cullingford, 9-32. London: Kogan Page. (*)

Landwehr, N. 2011. "Thesen zur Wirkung und Wirksamkeit der externen Schulevaluation [Theses on the impact and effectiveness of the external school evaluation]." In Wirkungen und Wirksamkeit der externen Schulevaluation, edited by C. Quesel, V. Husfeldt, N. Landwehr and N. Steiner, 35-70. Bern: hep.

Lawrenz, F., N. Keiser, and B. Lavoie. 2003. "Evaluative site visits: a methodological review." American Journal of Evaluation 24:341-352.

Learmonth, J. 2000. Inspection. What's in it for schools? London/New York: Routledge Falmer.

Lonsdale, P., and C. Parsons. 1998. "Inspection and the school improvement hoax." In School Improvement After Inspection? School and LEA Responses, edited by P. Earley, 110-125. London: Paul Chapman Publishing. (*)

Macbeath, J. 2008. The impact study on the effectiveness of external school review in enhancing school improvement through school self-evaluation in Hong Kong. Hong Kong: Education Bureau. (*)

MacKinnon, N. 2011. "The Urgent Need for New Approaches in School Evaluation to Enable Scotland's Curriculum for Excellence." Educational Assessment Evaluation and Accountability 23: 89-106.

Macnab, D. 2004. "Hearts, minds and external supervision of schools: direction and development." Educational Review 56:53-64.

Martin, S. 2005. "Evaluation, Inspection and the Improvement Agenda Contrasting Fortunes in an Era of Evidence-Based Policy-Making." Evaluation 11: 496-504.

Matthews, P., and P. Sammons. 2004. Improvement through inspection. An evaluation of the impact of Ofsted's work. London: Ofsted. (*)

McCrone, T, M. Coghlan, P. Wade, and P. Rudd. 2009. Evaluation of the impact of Section 5 inspections - Strand 3. Final report for Ofsted. Slough: National Foundation for Educational Research. (*)

McCrone, T, P. Rudd, S. Blenkinsop, and P. Wade. 2006. Impact of Section 5 Inspections: Maintained Schools in England. Slough: National Foundation for Educational Research. (*)

McCrone, T, P. Rudd, S. Blenkinsop, P. Wade, S. Rudd, and T. Yeshanew. 2007. Evaluation of the Impact of Section 5 Inspections. Slough: National Foundation for Educational Research. (*)

McFadden, A. 2003 "Future Perfect." Education Review 16 (2):65-69.

McNamara, G., and J. O'Hara. 2006. "Workable compromise or pointless exercise? School-based evaluation in the Irish context." Educational Management, Administration and Leadership 34:564-582. (*)

McNamara, G., J. O'Hara, P. L. Lisi, and S. Davidsdottir. 2011. "Operationalising Self-Evaluation in Schools: Experiences from Ireland and Iceland." Irish Educational Studies 30: 63-82.

National Foundation for Educational Research. 2009. New Inquiry into School Accountability. Slough, UK: National Foundation for Educational Research. (*)

Nevo, D. 2001. "School evaluation: internal or external?" Studies in Educational Evaluation 27 (2):95-106.

Nicolaidou, M., and M. Ainscow. 2005. "Understanding failing schools: perspectives from the inside." School Effectiveness and School Improvement 16 (3):229-248. (*)

OECD. 2013. Synergies for better learning. An international perspective on evaluation and assessment. In OECD Reviews of Evaluation and Assessment in Education. Paris: OECD.

Olsson, G. 2007. "School inspections - experiences in Sweden." In Schulinspektion: Evaluation, Rechenschaftslegung und Qualitätsentwicklung, edited by W. Böttcher and H.-G. Kotthoff, 43-54. Münster/New York/München/Berlin: Waxmann. (*) 
Ouston, J., and J. Davies. 1998. "OFSTED and afterwards? Schools' responses to inspection." In School improvement after inspection? School and LEA responses, edited by P. Earley, 13-24. London: Paul Chapman Publishing. (*)

Ouston, J., B. Fidler, and P. Earley. 1997. "What do schools do after Ofsted school inspections - or before?" School Leadership and Management 17:95-104. (*)

Ouston, J., B. Fidler, and P. Earley. 1995. "School Improvement through School Inspection?" AERA Conference, San Francisco. (*)

Penzer, G. 2011. School inspections: What happens next? Reading, UK: CfBT Education Trust.

Perryman, J. 2005. "School leadership and management after Special Measures: discipline without the gaze?" School Leadership and Management 25:281-297. (*)

Perryman, J. 2006. "Panoptic performativity and school inspection regimes: disciplinary mechanisms and life under special measures." Journal of Education Policy 21:147161. $(*)$

Perryman, J. 2007. "Inspection and emotion." Cambridge Journal of Education 37:173-190. (*)

Perryman, J. 2009. "Inspection and the fabrication of professional and performative processes." Journal of Education Policy 24:611-631. (*)

Petticrew, M., and H. Roberts. 2006. Systematic reviews in the social sciences. A practical guide. Oxford, UK: Blackwell Publishing.

Reid, M. 2010. "Head's suicide was 'inextricably linked' to damning school inspection." The Times, January 20. http://www.timesonline.co.uk/tol/news/uk/scotland/article6994581.ece.

Richards, C. 2001. "School inspection: a re-appraisal." Journal of Philosophy of Education 35 (4):655-665.

Sammons, P. 2008. "Zero Tolerance of Failure and New Labour Approaches to School Improvement in England." Oxford Review of Education 34: 651-64.

Sandbrook, I. 1996. Making sense of primary inspection. Buckingham, UK/Bristol, USA: Open University Press. $(*)$

Scanlon, M. 1999. The impact of Ofsted inspections. Slough, UK: National Foundation for Educational Research. (*)

Schagen, S., and C. Wylie. 2009. School resources, culture and connections. In NZCER National Survey Thematic Report. Wellington: NZCER. (*)

Schutz, P.A., J.Y. Hong, D.I. Cross, and J.N. Osbon. 2006. "Reflections on investigating emotion in educational activity settings." Educational Psychology Review 18 (4):343-360.

Sherman, L.W., D.C. Gottfredson, D.L. MacKenzie, J. Eck, P. Reuter, and S.D. Bushwa. 1998. Preventing Crime: What Works, What Doesn't, What's Promising. In Research in Brief. Washington, DC: U.S. Department of Justice.

Sommer, N., and E. Schwank. 2011. Evaluationsbefragung zur Nachinspektion. Erste Ergebnisse 2011. Hildesheim: Niedersächsisches Landesinstitut für schulische Qualitätsentwicklung. (*)

Thomas, G. 1998. "A brief history of the genesis of the new schools' inspection system." British Journal of Educational Studies 46 (4):415-427.

Thomas, G., W. C. Yee, and J. Lee. 2000. "'Failing' special schools - action planning and recovery from special measures assessments." Research Papers in Education 15 (1):3-24. doi: 10.1080/026715200362925. (*)

Troman, G. 1997. "Self-management and school inspection: Complementary forms of surveillance and control in the primary school." Oxford Review of Education 23:345364. $(*)$

Troman, G., and P. Woods. 2009. "Careers under stress: Teacher adaptations at a time of intensive reform." In Teachers' careers trajectories and work lives, edited by M. Bayer. Springer.

van Amelsvoort, G. H. W. C. H. , K. T. Bos, F. J. G. Janssens, L. Klaver, J. Lelyveld, and M. Pol. 2006. Proportional supervision and school improvement from an international perspective. Utrecht: Inspectie van het Onderwijs.

Van Bruggen, J.C. 2010. Inspectorates of Education in Europe; some Comparative Remarks about their Tasks and Work. Brussels: SICI.

Vandenberghe, R., and A.M. Huberman. 1999. Understanding and preventing teacher burnout. Cambridge, UK: Cambridge University Press.

Waldegrave, H., and J. Simons. 2014. Watching the watchmen. The future of school inspections in England. London: Policy Exchange.

Watling, R., D. Hopkins, A. Harris, and J. Beresford. 1998. "Between the devil and the deep blue sea? Implication for school and LEA development following an accelerated inspection programme." In No quick fixes. Perspectives on schools in difficulty, edited by Louise Stoll and K. Myers, 47-63. Bristol, UK: Falmer Press. (*) 
Webb, R., G. Vulliamy, K. Hakkinen, and S. Hamalainen. 1998. "External inspection or school self-evaluation? A comparison analysis of policy and practice in primary schools in England and Finland." British Educational Research Journal 24:539-556. (*)

Wilcox, B., and J. Gray. 1995. "Reactions to inspection: A study of three variants." In Good school, bad school: evaluating performance and encouraging improvement, edited by J. Gray and B. Wilcox, 149-166. Buckingham, UK/Philadelphia, USA: Open University Press. (*)

Wilcox, B., and J. Gray. 1996. Inspecting schools: Holding schools to account and helping schools to improve. Buckingham, UK: Open University Press. (*)

Winch, C. 2001. "Towards a non-punitive school inspection regime." Journal of Philosophy of Education 35 (4):683-694. 


\begin{tabular}{|c|c|c|c|c|c|c|c|c|c|}
\hline & 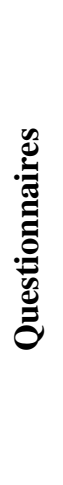 & 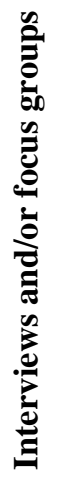 & 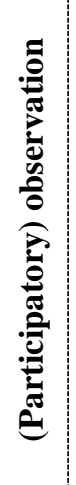 & 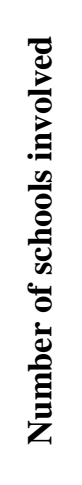 & 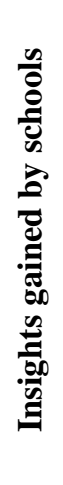 &  & 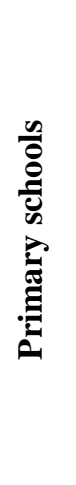 & 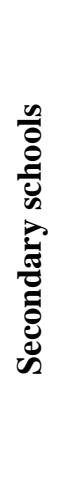 & 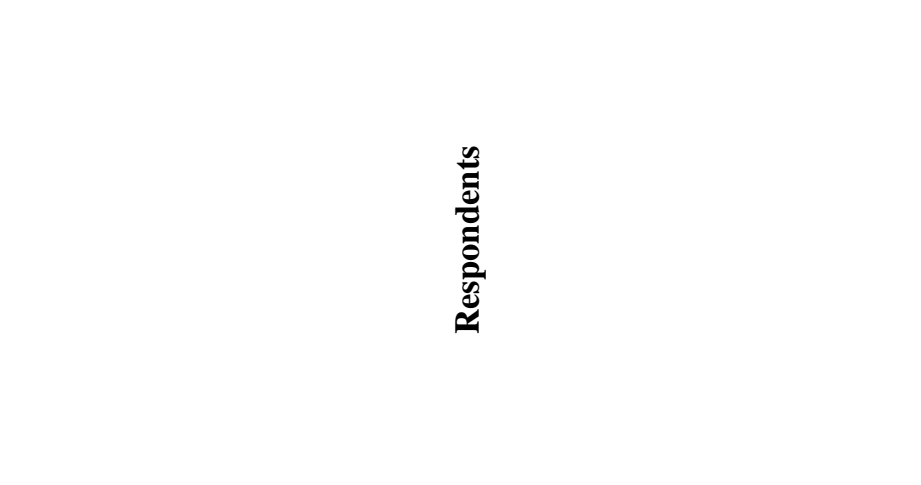 \\
\hline $\begin{array}{l}\text { Brimblecombe \& Ornston, } \\
\text { 1995/Brimblecombe, Shaw \& } \\
\text { Ornston, } 1996\end{array}$ & $\mathrm{X}$ & $\mathrm{X}$ & & 35 & & $\mathrm{X}$ & & $\mathrm{X}$ & $\begin{array}{l}\text { Questionnaires: } 821 \text { teachers of } 35 \text { schools } \\
\text { Interviews: } 30 \text { staff members of } 5 \text { schools }\end{array}$ \\
\hline Brunsden \& Davies, 2006 & $\mathrm{X}$ & & & 1 & & $\mathrm{X}$ & $\mathrm{X}$ & & $\begin{array}{l}\text { Teaching and non-teaching staff, students on placement, } \\
\text { governors and members of PTA committee }\end{array}$ \\
\hline Case, Case \& Catling, 2000 & & $\mathrm{X}$ & $\mathrm{X}$ & 10 & & $\mathrm{X}$ & $\mathrm{X}$ & & Principals and teachers \\
\hline Chapman, 2001 & & $X$ & $\mathrm{X}$ & 5 & & $\mathrm{X}$ & & $\mathrm{X}$ & Principals and teachers \\
\hline Chapman, 2002 & & $\mathrm{X}$ & $\mathrm{X}$ & 10 & $\mathrm{X}$ & $\mathrm{X}$ & $\mathrm{X}$ & & Principals \\
\hline $\begin{array}{l}\text { Cuckle, Hodgson \& } \\
\text { Broadhead, 1998/Cuckle \& } \\
\text { Broadhead, } 1999\end{array}$ & $\mathrm{X}$ & $\mathrm{X}$ & & 124 & $\mathrm{X}$ & $\mathrm{X}$ & $\mathrm{X}$ & & Principals (124 questionnaires, 47 interviews) \\
\hline $\begin{array}{l}\text { Emmelot, Karsten, Ledoux \& } \\
\text { Vermeulen, } 2004\end{array}$ & $X$ & $\mathrm{X}$ & & 365 & $\mathrm{X}$ & & $\mathrm{X}$ & $\mathrm{X}$ & Principals \\
\hline $\begin{array}{l}\text { Ferguson, Earley, Ouston \& } \\
\text { Fidler, } 2000\end{array}$ & $X$ & & & 261 & & $\mathrm{X}$ & $\mathrm{X}$ & & Principals \\
\hline $\begin{array}{l}\text { Gärtner, Hüsemann \& Pant, } \\
2009\end{array}$ & $\mathrm{X}$ & & & 182 & & $X$ & $\mathrm{X}$ & $\mathrm{X}$ & Principals \\
\hline Gray \& Gardner, 1999 & $X$ & $X$ & & 76 & & $\mathrm{X}$ & $X$ & $\mathrm{X}$ & $\begin{array}{l}\text { Interviews with } 5 \text { principals; questionnaires with principals of } 38 \\
\text { primary schools and } 38 \text { secondary schools. }\end{array}$ \\
\hline
\end{tabular}




\begin{tabular}{|c|c|c|c|c|c|c|c|c|c|}
\hline $\begin{array}{l}\text { Hopkins, Harris, Watling \& } \\
\text { Beresford, 1999/Watling, } \\
\text { Hopkins, Harris \& Beresford, } \\
1998\end{array}$ & $\mathrm{X}$ & $\mathrm{X}$ & & 76 & $\mathrm{X}$ & $\mathrm{X}$ & $\mathrm{X}$ & $\mathrm{X}$ & $\begin{array}{l}\text { Questionnaires with principals of } 62 \text { primary schools and } 14 \\
\text { secondary schools; Interviews with OFSTED members and staff } \\
\text { at LEA }\end{array}$ \\
\hline Hosker \& Robb, 1998 & $\mathrm{X}$ & $\mathrm{X}$ & & 1 & & $\mathrm{X}$ & $\mathrm{X}$ & & Staff members, governing body and parents \\
\hline Jeffrey \& Woods, 1996 & & $\mathrm{X}$ & $\mathrm{X}$ & 1 & & $\mathrm{X}$ & $\mathrm{X}$ & & Principal and teachers \\
\hline $\begin{array}{l}\text { Kelchtermans \& } \\
\text { Vandenberghe, } 1998\end{array}$ & $\mathrm{X}$ & $\mathrm{X}$ & $\mathrm{X}$ & 16 & $\mathrm{X}$ & $\mathrm{X}$ & $\mathrm{X}$ & & $\begin{array}{l}\text { Principals and teachers } \\
\text { Interviews and observation: } 4 \text { schools; } \\
\text { Questionnaire, observations and interviews: } 12 \text { schools }\end{array}$ \\
\hline $\begin{array}{l}\text { Kogan \& Maden, 1999/Jones, } \\
\text { Bealey, Kogan \& Maden, } \\
1999\end{array}$ & $\mathrm{X}$ & $\mathrm{X}$ & & & $\mathrm{X}$ & $\mathrm{X}$ & $\mathrm{X}$ & $\mathrm{X}$ & Governors, teachers, principals and parents \\
\hline Lonsdale \& Parsons, 1998 & & $\mathrm{X}$ & & 5 & $\mathrm{X}$ & $\mathrm{X}$ & $\mathrm{X}$ & $\mathrm{X}$ & Principals, governors, heads of department \\
\hline Macbeath, 2008 & $\mathrm{x}$ & $\mathrm{x}$ & $\mathrm{x}$ & 648 & $\mathrm{X}$ & $\mathrm{X}$ & $\mathrm{X}$ & $\mathrm{X}$ & $\begin{array}{l}\text { Questionnaires: principals and teachers } \\
\text { Interviews: key stakeholders } \\
\text { Observation: teachers (16 schools) }\end{array}$ \\
\hline Matthews \& Sammons, 2004 & $\mathrm{X}$ & & & $\begin{array}{l}3000 \\
+\end{array}$ & $\mathrm{X}$ & & $\mathrm{X}$ & $\mathrm{X}$ & Principals and teachers \\
\hline $\begin{array}{l}\text { Mccrone et al, 2007/National } \\
\text { Foundation for Educational } \\
\text { Research, } 2009\end{array}$ & $\mathrm{X}$ & $\mathrm{X}$ & & 1597 & $\mathrm{X}$ & $\mathrm{X}$ & $\mathrm{X}$ & $\mathrm{X}$ & $\begin{array}{l}\text { Questionnaires: mainly principals } \\
\text { Interviews: } 169 \text { principals, senior leaders, governors and parents } \\
\text { and } 243 \text { pupils (in small groups) in } 36 \text { schools }\end{array}$ \\
\hline $\begin{array}{l}\text { Mccrone, Coghlan, Wade \& } \\
\text { Rudd, } 2009\end{array}$ & $\mathrm{X}$ & $\mathrm{X}$ & & 126 & $\mathrm{X}$ & & $X$ & $\mathrm{X}$ & $\begin{array}{l}\text { Questionnaires: principals } \\
\text { Interviews: } 96 \text { principals, teachers and teacher assistants of } 18 \\
\text { schools }\end{array}$ \\
\hline $\begin{array}{l}\text { Mccrone, Rudd, Blenkinsop } \\
\text { \& Wade, } 2006\end{array}$ & $\mathrm{X}$ & $\mathrm{X}$ & & 134 & $\mathrm{X}$ & $\mathrm{X}$ & $X$ & $\mathrm{X}$ & $\begin{array}{l}\text { Questionnaires: } 134 \text { principals } \\
\text { Interviews: senior leaders and governors of } 36 \text { schools }\end{array}$ \\
\hline McNamara \& O’Hara, 2006 & & $\mathrm{X}$ & & 8 & & $X$ & $X$ & $\mathrm{X}$ & Interviews with (vice) principals of 8 schools \\
\hline Nicolaidou \& Ainscow, 2005 & & $\mathrm{X}$ & $\mathrm{X}$ & 4 & & $\mathrm{X}$ & $\mathrm{X}$ & & Principals and teachers of schools into special measures \\
\hline $\begin{array}{l}\text { Ouston, Fidler, \& Earley, } \\
\text { 1995, 1997/Earley, } \\
\text { 1998/Ouston \& Davies, } 1998\end{array}$ & $\mathrm{X}$ & $\mathrm{X}$ & & 170 & $\mathrm{X}$ & $X$ & & $\mathrm{X}$ & Mainly principals \\
\hline Perryman, 2005, 2006, 2007, & & $\mathrm{X}$ & $\mathrm{X}$ & 1 & & $X$ & & $\mathrm{X}$ & Principal and teachers of a school into special measures \\
\hline
\end{tabular}




\begin{tabular}{|c|c|c|c|c|c|c|c|c|c|}
\hline \multicolumn{10}{|l|}{2009} \\
\hline Sandbrook, 1996 & & $\mathrm{X}$ & & 12 & & $X$ & $\mathrm{X}$ & & Principals, teachers and inspectors \\
\hline Scanlon, 1999 & $\mathrm{X}$ & $\mathrm{X}$ & & 428 & $X$ & $\mathrm{X}$ & $\mathrm{X}$ & $\mathrm{X}$ & $\begin{array}{l}\text { Principals and teachers (both schools into special measures, } \\
\text { and schools not into special measures) }\end{array}$ \\
\hline Schagen \& Wylie, 2009 & $\mathrm{X}$ & & & 196 & $\mathrm{X}$ & & $\mathrm{X}$ & $\mathrm{X}$ & Principals \\
\hline Sommer \& Schwank, 2011 & $\mathrm{X}$ & & & 27 & & $\mathrm{X}$ & $\mathrm{X}$ & $\mathrm{X}$ & Principals \\
\hline $\begin{array}{l}\text { Swedish National Financial } \\
\text { Management Authority, } 2005 \\
(*)\end{array}$ & $\mathrm{X}$ & & & 307 & $\mathrm{X}$ & & & $\mathrm{X}$ & Principals \\
\hline Thomas, Yee \& Lee, 2000 & & $\mathrm{X}$ & & 14 & & $\mathrm{X}$ & & & $\begin{array}{l}\text { Senior management team, governors, staff, parents and pupils of } \\
\text { special schools into special measures }\end{array}$ \\
\hline Troman, 1997 & & $\mathrm{X}$ & $X$ & 1 & & $\mathrm{X}$ & $\mathrm{X}$ & & Principal, senior managers and staff \\
\hline $\begin{array}{l}\text { Webb, Vulliamy, Hakkinen \& } \\
\text { Hamalainen, } 1998\end{array}$ & & $\mathrm{X}$ & $X$ & 6 & & $\mathrm{X}$ & $\mathrm{X}$ & & Teachers, other staff members and pupils \\
\hline Wilcox \& Gray, 1995 & & $\mathrm{X}$ & & 3 & $\mathrm{X}$ & $\mathrm{X}$ & $\mathrm{X}$ & & Principals, deputy principals, teachers and inspectors \\
\hline Wilcox \& Gray, 1996 & & $\mathrm{X}$ & & 24 & $\mathrm{X}$ & $\mathrm{X}$ & $\mathrm{X}$ & $\mathrm{X}$ & Principals, teachers and inspectors \\
\hline
\end{tabular}

(*) reported by Olsson (2007) 
Table 2. Overview of reviewed studies by method and focus

\begin{tabular}{|c|c|c|c|}
\hline & $\begin{array}{l}\text { Insights gained by } \\
\text { schools }\end{array}$ & Emotional consequences & $\begin{array}{l}\text { Learning effects and } \\
\text { emotional consequences }\end{array}$ \\
\hline Quantitative methods & $\begin{array}{l}3 \text { studies: Matthews \& } \\
\text { Sammons, 2004; Schagen } \\
\text { \& Wylie, 2009; Swedish } \\
\text { National Financial } \\
\text { Management Authority, } \\
\text { 2007. }\end{array}$ & $\begin{array}{l}4 \text { studies: Brunsden \& } \\
\text { Davies, 2006; Ferguson, } \\
\text { Earley, Ouston \& Fidler, } \\
\text { 2000; Gärtner, Hüsemann } \\
\text { \& Pant, 2009; Sommer \& } \\
\text { Schwank, 2011. }\end{array}$ & \\
\hline Qualitative methods & & $\begin{array}{l}10 \text { studies: Case, Case \& } \\
\text { Catling, 2000; Chapman, } \\
\text { 2001; Jeffrey \& Woods, } \\
\text { 1996; McNamara \& } \\
\text { O'Hara, 2006; } \\
\text { Nicolaidou \& Ainscow, } \\
\text { 2005; Perryman, 2005, } \\
\text { 2006, 2007, 2009; } \\
\text { Sandbrook, 1996; } \\
\text { Thomas, Yee \& Lee, } \\
\text { 2000; Troman, 1997; } \\
\text { Webb, Vulliamy, } \\
\text { Hakkinen \& Hamalainen, } \\
\text { 1998. }\end{array}$ & $\begin{array}{l}4 \text { studies: Chapman, } \\
\text { 2002; Lonsdale \& } \\
\text { Parsons, 1998; Wilcox \& } \\
\text { Gray, 1995; Wilcox \& } \\
\text { Gray, } 1996 .\end{array}$ \\
\hline Mixed Methods & $\begin{array}{l}2 \text { studies: Emmelot, } \\
\text { Karsten, Ledoux \& } \\
\text { Vermeulen, 2004; } \\
\text { McCrone et al., 2009. }\end{array}$ & $\begin{array}{l}4 \text { studies: Brimblecombe } \\
\text { \& Ornston, 1995; Cuckle, } \\
\text { Hodgson \& Broadhead, } \\
\text { 1998; Gray \& Gardner, } \\
\text { 1999; Hosker \& Robb, } \\
\text { 1998. }\end{array}$ & $\begin{array}{l}8 \text { studies: Hopkins, } \\
\text { Harris, Watling \& } \\
\text { Beresford, 1999; } \\
\text { Kelchtermans \& } \\
\text { Vandenberghe, 1998; } \\
\text { Kogan \& Maden, 1999; } \\
\text { MacBeath, 2008; } \\
\text { McCrone et al., 2006; } \\
\text { McCrone et al., 2007; } \\
\text { Ouston, Fidler \& Earley, } \\
\text { 1995; Scanlon, 1999. }\end{array}$ \\
\hline
\end{tabular}

